E3S Web of Conferences 1, 04004 (2013)

DOI: $10.1051 / \mathrm{e} 3 \operatorname{sconf} / 20130104004$

(C) Owned by the authors, published by EDP Sciences, 2013

\title{
Zinc fractionation in the rhizosphere of wheat (Triticum aestivum L.) plant in soils treated with sewage sludge
}

\author{
A. R. Hosseinpur ${ }^{1}$ and H. R. Motaghian ${ }^{2}$ \\ ${ }^{1}$ Soil Science Department, Faculty of Agriculture, Shahrekord University, P.O. Box 115, Shahrekord, Iran, hosseinpur- \\ a@agr.sku.ac.ir \\ ${ }^{2}$ Soil Science Department, Faculty of Agriculture, Shahrekord University, P.O. Box 115, Shahrekord, Iran, \\ hrm_61@yahoo.com
}

\begin{abstract}
Rhizosphere is a microbiosphere and has quite different chemical, physical and biological properties from bulk soils. A greenhouse experiment was performed to compare fractionation of Zinc ( $\mathrm{Zn}$ ) between rhizosphere and bulk soils amended with sewage sludge (1\% w/w of sewage sludge to soil). Fractions of $\mathrm{Zn}$ were determined in two subsamples (rhizosphere and bulk soils). The results indicated concentration of $\mathrm{Zn}$-fractions (except carbonates-associated) in the rhizosphere soils were significantly $(\mathrm{p}<0.05)$ different from concentrations of $\mathrm{Zn}$-fractions in the bulk soils. Also, results revealed that significant correlation $(\mathrm{p}<0.05)$ between $\mathrm{Zn}$ associated with iron-manganese and yield and uptake indices in the rhizosphere and bulk soils were found. The results of this research illustrated that rhizosphere is a small zone but important environmental zone in soils with quite different properties.
\end{abstract}

Key words: Rhizosphere; Zinc; Fractionation technique;

\section{Introduction}

Rhizosphere is commonly defined as the zone where root activity influences significantly the biological and chemical properties of the soil (Chen et al., 2006). Thus the chemical and biological characteristics of the rhizosphere soils can be very different from those of the bulk soils surrounding them. Plant roots release continuously compounds, such as sugars, amino acids, organic acids and vitamins, which serve as substrates for microorganisms (Szmigielska et al., 1996). The different chemical and biological conditions of the rhizosphere with respect to the nonrhizosphere soil (bulk soil) can affect metal fractions in soil and therefore bioavailability (Dessureault-Rompre et al., 2008).

Sewage sludge is an important source of nutrients such as $\mathrm{Zn}$ and organic matter since a few decades, sewage sludge have been increasingly used in numerous countries around the world as fertilizers on farm lands because of their high content of organic matter and essential nutrients that favor crop growth (Renoux et al., 2007).

Plants have the potential to transform metal species for easier uptake through root exudation or $\mathrm{pH}$ changes in the rhizosphere (Whiting et al., 2001). Following the observation that the measurement of free metal ion activities in soil solution before plant growth did not provide the best prediction of metal supply to the plant (Nolan et al., 2005), it remains a controversial issue whether plants predominantly absorb free metal ions from soil solution (Hamon et al., 1995). For this reason, determining $\mathrm{Zn}$ fractions in the rhizosphere as the zone where root activity influences significantly and understanding subsequent $\mathrm{Zn}$ uptake by plants are currently subjects of much research (Martinez-Alcala et al. 2010). Wang et al. (2002) stated that fractionation differences were observed for $\mathrm{Zn}$ between the wheat (Triticum aestivum L.) rhizosphere and bulk soil.

Studies dealing with the rhizosphere are important to determine the dynamics of nutrient changes in soils (Hinsinger, 2001) and needs to evaluate $\mathrm{Zn}$-fractions in amended soils with sewage sludge. Therefore, the objectives of the present study were to evaluate fractions of $\mathrm{Zn}$ in bulk and rhizosphere amended soils with sewage sludge.

\section{Materials and Methods}

Ten soil samples were collected from Chaharmahal-VaBakhtiari province, in central Iran. Particle size 
Table 1. Selected properties of soils

\begin{tabular}{|c|c|c|c|c|c|c|c|c|c|}
\hline \multirow{2}{*}{ Soil No. } & clay & silt & $\mathrm{CaCO}_{3}$ & TOC & \multirow{2}{*}{$\mathrm{pH}$} & \multirow{2}{*}{ 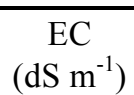 } & \multirow{2}{*}{$\begin{array}{c}\mathrm{CEC} \\
\left(\mathrm{cmol}_{\mathrm{c}} \mathrm{kg}^{-1}\right)\end{array}$} & \multirow{2}{*}{$\begin{array}{l}\text { Available } \mathrm{Zn} \\
\left(\mathrm{mg} \mathrm{kg}^{-1}\right)\end{array}$} & \multirow{2}{*}{$\begin{array}{l}\text { Total } \mathrm{Zn} \\
\left(\mathrm{mg} \mathrm{kg}^{-1}\right)\end{array}$} \\
\hline & \multicolumn{4}{|c|}{$(\%)$} & & & & & \\
\hline 1 & 55 & 40 & 28.7 & 0.72 & 7.8 & 0.13 & 20.9 & 0.50 & 57 \\
\hline 2 & 53 & 44 & 35.6 & 0.30 & 8.1 & 0.13 & 19.3 & 0.59 & 54 \\
\hline 3 & 49 & 39 & 29.4 & 0.51 & 7.9 & 0.12 & 22.5 & 0.34 & 45 \\
\hline 4 & 46 & 42 & 26.4 & 0.71 & 7.8 & 0.14 & 21.6 & 0.75 & 45 \\
\hline 5 & 41 & 42 & 32.2 & 0.54 & 8.1 & 0.13 & 16.0 & 0.54 & 37 \\
\hline 6 & 37 & 44 & 32.5 & 0.80 & 7.6 & 0.16 & 15.6 & 0.66 & 44 \\
\hline 7 & 25 & 33 & 41.0 & 0.47 & 7.7 & 0.21 & 11.5 & 0.77 & 34 \\
\hline 8 & 38 & 55 & 23.1 & 1.19 & 8.1 & 0.24 & 17.9 & 0.73 & 58 \\
\hline 9 & 48 & 46 & 11.3 & 1.16 & 7.8 & 0.25 & 18.5 & 1.31 & 54 \\
\hline 10 & 49 & 46 & 14.8 & 0.97 & 7.9 & 0.23 & 17.9 & 0.39 & 56 \\
\hline
\end{tabular}

Available Zn: Zn extracted using DTPA-TEA.

distribution, Electrical conductivity (EC), pH, Organic carbon, equivalent calcium carbonate and cation exchange capacity were determined by standard methods. Total and available $\mathrm{Zn}$ was determined using $4 \mathrm{M} \mathrm{HNO}_{3}$ (Sposito et al. 1982) and DTPA-TEA (Lindsay and Norvell, 1978) respectively. Value of $\mathrm{pH}$ in sewage sludge was 7.5. Electrical conductivity was $2.25 \mathrm{dS} \mathrm{m}^{-1}$. Organic carbon was $38 \%$. Also, the available and total concentrations of $\mathrm{Zn}$ were 558 and $1321 \mathrm{mg} \mathrm{kg}^{-1}$, respectively.

A homemade rhizobox (Wang et al. 2002) was used to plant wheat. The dimension of the rhizobox was $200 \mathrm{~mm} \times 130 \mathrm{~mm} \times 200 \mathrm{~mm}$ (length $\times$ width $\times$ height $)$. The rhizobox was divided into three sections: a central zone or rhizosphere zone $(30 \mathrm{~mm}$ in width), which was surrounded by nylon cloth (300 mesh), and left and right nonrhizosphere zones (bulk soil) (50 $\mathrm{mm}$ in width). One percentage $(\mathrm{w} / \mathrm{w})$ of sewage sludge was added to soils, and then amended soils were incubated at field capacity, for 1 month. After incubation, soils were air-dried. Three seeds were sown per rhizosphere zone. Plants were grown under greenhouse conditions. The aboveground parts of the plants were first harvested as shoots. The rhizobox was then dismantled. The rhizosphere soil was sieved gently to remove the roots by keeping the root mass intact as much as possible. The soils taken from rhizosphere soil zone and two bulk soil zones of the left and right were mixed separately for further analysis. Shoots were rinsed with deionized water, and then dried at $70{ }^{\circ} \mathrm{C}$ for $48 \mathrm{~h}$, and the dried sample was finely ground for analysis. $\mathrm{Zn}$ concentration was extracted using dry ash in shoot (Campbell and Plank, 1998) and then concentrations of $\mathrm{Zn}$ were determined using an atomic absorption spectrophotometer (model G.B.C 932).

In the bulk and the rhizosphere soils exchangeable $\mathrm{Zn}$ (EXCH-Zn), Zn associated with carbonates (CARB$\mathrm{Zn}$ ), $\mathrm{Zn}$ associated with manganese-iron oxides (OXIDS$\mathrm{Zn}$ ) and $\mathrm{Zn}$ associated with organic matter fractions (OM$\mathrm{Zn}$ ) were determined based on that employed by Tessier et al. (1979) and residual fraction (RES-Zn) was determined using $4 \mathrm{M} \mathrm{HNO}_{3}$ (Sposito et al. 1982).
The significant differences of $\mathrm{Zn}$ fractions, between rhizosphere and bulk soils were determined by using paired-samples t-test.

\section{Results and Discussion}

Selected chemical and physical properties of the soils studied are given in Table 1 . These results showed that there was a wide variation in the selected chemical and physical properties of the soils. Clay contents in all soils averaged 44 and ranged from 25 to $55 \%$. The soils were alkaline and low in EC and organic matter. The CEC ranged from 11.5 to $22.5 \mathrm{cmol}_{\mathrm{c}} \mathrm{kg}^{-1}$. The available $\mathrm{Zn}$ ranged from 0.34 to $1.31 \mathrm{mg} \mathrm{kg}^{-1}$. The total $\mathrm{Zn}$ in all soils ranged from 34 to $58 \mathrm{mg} \mathrm{kg}^{-1}$.

The amounts of $\mathrm{Zn}$ fractions in the rhizosphere and bulk soils using the sequential extraction method are shown in Table 2. The results of this table show that concentrations of $\mathrm{Zn}$-fractions (except carbonateassociated $)$ in the rhizosphere were significantly $(p<0.05)$ different from concentrations of Zn-fractions in the bulk soils. The exchangeable fraction and $\mathrm{Zn}$ associated with organic matter were decreased in the rhizosphere soil. Whereas $\mathrm{Zn}$ associated with iron-manganese oxides and residual fractions were increased in the rhizosphere soils. The average of exchangeable fraction and $\mathrm{Zn}$ associated with organic carbon in the rhizosphere soils were 0.16 $\left(0.25 \%\right.$ of total) and $1.16(1.78 \%$ of total $) \mathrm{mg} \mathrm{kg} \mathrm{kg}^{-1}$ respectively, whereas the average of these fractions were $0.22\left(0.36 \%\right.$ of total) and 1.27 (2.07\% of total) $\mathrm{mg} \mathrm{kg}^{-1}$ in the bulk soils respectively. Also, the average of $\mathrm{Zn}$ associated with iron-manganese oxides and residual fraction were 12.92 (19.82\% of total) and $50.3(77.19 \%$ of total) $\mathrm{mg} \mathrm{kg}^{-1}$ in the rhizosphere soils respectively, whereas in the bulk soils the average of $\mathrm{Zn}$ associated with iron-manganese oxides and residual fractions were $11.75\left(19.06 \%\right.$ of total) and $47.8(77.52 \%$ of total $) \mathrm{mg} \mathrm{kg}^{-}$ 1 , respectively.

The decrease in exchangeable fraction was reported by Youssef and Chino (1989). The exchangeable and water-soluble fractions may recomplexed by organic material secreted by roots (Marschner et al., 1989), 
Table 2. Zn concentration ( $\mathrm{mg} \mathrm{kg}^{-1}$ ) in different fractions in the rhizosphere (R) and the bulk (B) soils

\begin{tabular}{|c|c|c|c|c|c|c|c|c|c|c|}
\hline \multirow{2}{*}{ Soil No. } & \multicolumn{2}{|c|}{ EXCH-Zn } & \multicolumn{2}{|c|}{ CARB-Zn } & \multicolumn{2}{|c|}{ OXIDS-Zn } & \multicolumn{2}{|c|}{ OM-Zn } & \multicolumn{2}{|c|}{ RES-Zn } \\
\hline & $\mathrm{R}$ & $\mathrm{B}$ & $\mathrm{R}$ & $\mathrm{B}$ & $\mathrm{R}$ & $\mathrm{B}$ & $\mathrm{R}$ & $\mathrm{B}$ & $\mathrm{R}$ & $\mathrm{B}$ \\
\hline 1 & $0.16 \mathrm{~b}$ & $0.22 \mathrm{a}$ & $0.43 a$ & $0.39 \mathrm{a}$ & $9.94 a$ & $9.27 b$ & $1.13 b$ & $1.60 \mathrm{a}$ & $61.4 \mathrm{a}$ & $55.5 b$ \\
\hline 2 & $0.15 b$ & $0.21 \mathrm{a}$ & $0.39 \mathrm{a}$ & $0.41 \mathrm{a}$ & $10.71 \mathrm{a}$ & $7.77 b$ & $1.40 \mathrm{a}$ & $1.41 \mathrm{a}$ & $57.2 \mathrm{a}$ & $53.9 \mathrm{~b}$ \\
\hline 3 & $0.14 \mathrm{~b}$ & $0.20 \mathrm{a}$ & $0.38 \mathrm{a}$ & $0.40 \mathrm{a}$ & $12.27 \mathrm{a}$ & $12.21 \mathrm{a}$ & $0.80 \mathrm{~b}$ & $1.03 \mathrm{a}$ & $48.4 \mathrm{a}$ & $46.6 \mathrm{~b}$ \\
\hline 4 & $0.15 b$ & $0.21 \mathrm{a}$ & $0.46 \mathrm{a}$ & $0.47 \mathrm{a}$ & $14.71 \mathrm{a}$ & $14.02 b$ & $1.24 \mathrm{a}$ & $1.25 \mathrm{a}$ & $50.5 \mathrm{a}$ & $48.7 \mathrm{~b}$ \\
\hline 5 & $0.15 b$ & $0.22 \mathrm{a}$ & $0.75 \mathrm{a}$ & $0.78 \mathrm{a}$ & $12.43 \mathrm{a}$ & $10.68 b$ & $1.00 \mathrm{a}$ & $1.02 \mathrm{a}$ & $43.5 \mathrm{a}$ & $42.6 \mathrm{~b}$ \\
\hline 6 & $0.16 \mathrm{~b}$ & $0.23 \mathrm{a}$ & $0.85 \mathrm{a}$ & $0.69 \mathrm{~b}$ & $14.33 \mathrm{a}$ & $13.83 b$ & $1.19 \mathrm{~b}$ & $1.30 \mathrm{a}$ & $45.7 \mathrm{a}$ & $39.0 \mathrm{~b}$ \\
\hline 7 & $0.18 b$ & $0.24 \mathrm{a}$ & $1.24 \mathrm{a}$ & $1.10 \mathrm{~b}$ & $14.66 \mathrm{a}$ & $13.84 b$ & $1.14 \mathrm{~b}$ & $1.23 \mathrm{a}$ & $36.9 \mathrm{a}$ & $34.0 \mathrm{~b}$ \\
\hline 8 & $0.19 b$ & $0.24 \mathrm{a}$ & $0.51 \mathrm{a}$ & $0.52 \mathrm{a}$ & $12.30 \mathrm{a}$ & $10.85 b$ & $1.08 \mathrm{~b}$ & $1.21 \mathrm{a}$ & $53.2 \mathrm{a}$ & $53.0 \mathrm{a}$ \\
\hline 9 & $0.18 b$ & $0.26 \mathrm{a}$ & $0.71 \mathrm{a}$ & $0.78 \mathrm{~b}$ & $16.45 \mathrm{a}$ & $15.05 b$ & $1.28 \mathrm{~b}$ & $1.32 \mathrm{a}$ & $49.1 \mathrm{a}$ & $48.5 b$ \\
\hline 10 & $0.18 \mathrm{a}$ & $0.21 \mathrm{a}$ & $0.50 \mathrm{a}$ & $0.56 \mathrm{~b}$ & $11.44 \mathrm{a}$ & $9.95 b$ & $1.22 \mathrm{~b}$ & $1.37 \mathrm{a}$ & $57.6 \mathrm{a}$ & $56.0 \mathrm{~b}$ \\
\hline mean & $0.16 \mathrm{~B}$ & $0.22 \mathrm{~A}$ & $0.62 \mathrm{~A}$ & $0.61 \mathrm{~A}$ & $12.92 \mathrm{~A}$ & $11.75 \mathrm{~B}$ & $1.16 \mathrm{~B}$ & $1.27 \mathrm{~A}$ & $50.3 \mathrm{~A}$ & $47.8 \mathrm{~B}$ \\
\hline
\end{tabular}

Data of different fractions in the bulk and rhizosphere of each soil followed by the different letters are significantly different $(\mathrm{P}<0.05)$.

Means in final row for different fractions followed by the different letters are significantly different $(\mathrm{P}<0.01)$.

therefore these fractions were reduced in rhizosphere soil of wheat. Therefore a reasonable explanation for the change in exchangeable $\mathrm{Zn}$ is transformation from exchangeable $\mathrm{Zn}$ to other fractions. Increase in the $\mathrm{Zn}$ associated with iron-manganese oxides can be attributed to oxidize the organic materials by microorganism (Jones et al., 1996). Therefore $\mathrm{Zn}$ associated with organic matter would release in rhizosphere soil, moreover hydrous iron oxides had a strong affinity for $\mathrm{Zn}$ sorption, but this fraction did not fix zinc in an unavailable form (Stanton and Berger, 1965), whereas it has been reported that the incorporation of manganese oxide into soil did not affect zinc availability (Mckenzine, 1978). Population of microorganism in the rhizosphere soils increased and therefore oxidation of organic materials has been increased. Thus Zn-associated with organic matter was released with oxidation of organic matter and organic compounds exuded and therewith $\mathrm{Zn}$ associated with iron oxides and residual $\mathrm{Zn}$ have been increased in the wheat rhizosphere. Martinez-Alcala et al. (2010) documented that the reaction of organic anions with $\mathrm{Zn}$ in soils depends not only on their complexation ability but also on their sorption/desorption reactions and their microbial degradability. They reported that the higher microbial biomass found in the rhizosphere soils, with respect to the bulk soils, may enhance the degradation of the organic compounds exuded by roots, fixation mechanisms in the soil being more relevant for $\mathrm{Zn}$ immobilisation. In the rhizosphere soils $\mathrm{Zn}$ associated with iron-manganese oxides and $\mathrm{Zn}$ uptake indices was significantly correlated $\left(\mathrm{r}=0.82^{* *}\right)$. Also, in the bulk soils $\mathrm{Zn}$ associated with iron-manganese oxides and $\mathrm{Zn}$ uptake indices was significantly correlated $\left(\mathrm{r}=0.80^{* *}\right)$. The results show that in the wheat rhizosphere significant correlation between $\mathrm{Zn}$ fractions and plant indices were higher than in the bulk soils. Similar our results were obtained by Maqsood et al. (2011). They indicated that the importance of ironmanganese oxides bound soil $\mathrm{Zn}$ in determining $\mathrm{Zn}$ phytoavailability even in calcareous soils.

\section{Conclusions}

This study illustrated that concentrations of $\mathrm{Zn}$-fractions (except carbonate-associated) in the rhizosphere were significantly different from concentrations of $\mathrm{Zn}$-fractions in the bulk soils. The correlation coefficients between $\mathrm{Zn}$ associated with iron-manganese oxides and plant indices were higher in the rhizosphere than in the bulk soils. The results showed that $\mathrm{Zn}$ associated with iron-manganese fractions was available for wheat. Research on rhizosphere has been a hotspot because of its important role in the agriculture and environments.

\section{References}

Campbell CR, Plank CO. Preparation of plant tissue for laboratory analysis. In Kalra Y.P. (Ed.), Handbook of Reference Methods for Plant Analysis. CRC Press, Taylor \& Francis Group. pp. 37-50.

Chen, Y. M.,Wang, M. K., Huang, P.M., 2006. Catechin transformation as influenced by aluminum. J. Agric. Food Chem., 54: 212-218.

Dessureault-Rompre, J., Nowack, B., Schulin, R., Tercier-Waeber, M.L., Luster, J., 2008. Metal solubility and speciation in the rhizosphere of Lupinus albus cluster roots. Environ. Sci. Technol., 42:7146-7151.

Hamon, R. E., Lorenz, S. E., Holm, P. E., Christensen, T. H. and McGrath, S. P. 1995. Changes in trace metal species and other components of the rhizosphere during growth of radish. Plant Cell Environ., 18: 749-756.

Hinsinger, P. 2001. Bioavailability of trace elements as related to root-induced chemical changes in the rhizosphere. In: Gobran, G.R., Wenzel, W.W. and Lombi, E. (Eds.) Trace Elements in the Rhizosphere. CRC Press, Boca Raton. 1998, pp. $25-$ 40 . 
Jones DL, Prabowo AM, Kochian LV. Kinetics of malate transport and decomposition in acid soil and isolated bacterial-populations-the effect of microorganisms on root exudation of malate under Al stress. Plant Soil, 1996, 182:239-247.

Lindsay WL, Norvell WA. Development of a DTPA soil test for zinc, iron, manganese, and copper. Soil Sci. Soc. Am. J. 1978, 42:421-428.

Maqsood MA, Hussain S, Aziz T. Ashraf M. Wheatexuded organic acids influence zinc release from calcareous soils. Pedosphere 2011, 21(5): 657-665.

Marschner H, Treeby M, Romheld V. Role of root induced changes in the rhizosphere for iron acquisition in higher plants. Z. Pflanzenernahr. Bodenk. 1989, 152:197-204.

Martinez-Alcala I, Walker DJ Bernal MP. Chemical and biological properties in the rhizosphere of Lupinus albus alter soil heavy metal fractionation. Ecotoxicology and Environmental Safety 2010, 73:595-602.

McKenzie RM. The effect of two manganese dioxides on the uptake of lead, nickel, copper and zinc by subterranean clover. Aust. J. Soil Res., 1978, 16:209-214.

Nolan AL, Zhang H, McLaughlin M.J. Prediction of zinc, cadmium, lead, and copper availability to wheat in contaminated soils using chemical speciation, diffusive gradients in thin films, extraction, and isotopic dilution techniques. J. Environ. Qual., 2005, 34: 496-507.

Sposito G, Lund LJ, Chang A. Trace metal chemistry in arid-zone field soils amended with sewage sludge. I.
Fractionation of $\mathrm{Ni}, \mathrm{Cu}, \mathrm{Zn}, \mathrm{Cd}$, and $\mathrm{Pb}$ in solid phases. Soil Sci. Soc. Am. J., 1982, 46: 260-264.

Stanton DA, Burger RT, Availability to plants of zinc sorbed by soil and hydrous iron oxides. Geoderma, 1967, 1:13-17.

Szmigielska AM, Van Rees KCJ, Cieslinski C, Huang PM. Low molecular weight dicarboxylic acids in rhizosphere soil of durum wheat. J. Agric. Food Chem. 1996, 44: 1036-1040.

Tessier A, Campbell PGC, Bisson M. Sequential extraction procedure for the speciation of particulate trace metals. Anal. Chem., 1979, 51:844- 851.

Wang Z, Shan XQ, Zhang S. Comparison between fractionation and bioavailability of trace elements in rhizosphere and bulk soils. Chemosphere, 2002, 46(8):1163-1171.

Whiting SN, Leake JR, McGrath SP, Baker AJM. Assessment of $\mathrm{Zn}$ mobilization in the rhizosphere of Thlaspi caerulescens by bioassay with nonaccumulator plants and soil extraction. Plant Soil, 2001, 237: 147-156.

Youssef RA, Chino M. Root-induced changes in the rhizosphere of plants. II. Distribution of heavy metals across the rhizosphere in soils. Soil Sci. Plant Nutr. 1989, 35:609-621.

Renoux AY, Rocheleau S, Sarrazin M, Sunahara GI, Blais, JF. Assessment of a sewage sludge treatment on cadmium, copper and zinc bioavailability in barley, ryegrass and earthworms. Environmental Pollution, 2007, 145: 41-50. 